\title{
Folkloric Axis of Relexified Language and the Subversion of Colonial Cultural Hierarchy
}

\author{
Dr. Razieh Eslamieh \\ Islamic Azad University Parand Branch \\ e-mail: eslami_paranduniv@yahoo.com
}

\section{Doi:10.5901/ajis.2013.v2n9p487}

\section{Abstract}

Language has an aspect of universality and another aspect of particularity. Ethnic culture is conveyed through the aspect of particularity, and that is the very point which makes a nation particular and its culture distinct. Colonization by imposing colonial language and non-native cultural poetics perishes the aspect of particularity of the substrate language. However, the counteracting strategy of relexification appeals to the universality of superstrate language to transmit the particularity of substrate language. Ethnic folk stories, myths, mythical elements, fables, parables, proverbs, and idioms are interposed on the colonial language to make ethnic colonized culture universally palpable. In this regard, the aspect of universality is provided by the colonial superstrate language and the aspect of particularity by the colonized ethnic language. In general, because of the ubiquity of mythic elements in time and place, the folkloric aspect of relexified language gives nations the sense of dignified historical background and makes the relexified work relevant to a multitude of societies, rather than just one ethnic local community. This paper deals with the way Chinua Achebe uses the folkloric axis of relexified language to bring the particularities of Ibo culture on universal scale and above all to restore the dignity of lbo cultural identity which was lost through colonial discourse: "Thus, as represented by Chinua Achebe, and contrary to the discourse of colonial anthropology, Umuofia, the primordial Igbo village emerges as a locus of reflective civility" (Irele 9). Achebe's relexified language gives voice to Ibo experience throughout the English speaking world.

Language has an aspect of universality and another aspect of particularity. The capacity to speak and order the verbal or written signs in a manner that makes communication possible forms the universal aspects of all languages and derives from the universal fundamental raison d'être of languages regarding the survival of the human against nature. Though, every language is distinguishable from other languages based on the particularity of sounds, words, phrases, narrative structures, and narrative rhythm which overall form the particularity of language. Ethnic culture is carried on through the particularity of language, rather than its universality shared by all races, and that is the very point which makes a nation particular and its culture distinct.

Colonization first and foremost embarks on destroying the particularity of an ethnic language, preserving merely its universality, so that the transmission of culture from generation to generation comes to a dead point. While colonial language brings with it Western canonical literature and imposes non-native cultural poetics which can perish the aspect of the particularity of the substrate language, the counteracting strategy of relexified language appeals to the universality of superstrate language to transmit the particularity of substrate language.

Achebe restores the particularity of Ibo through the universality of communicative means provided by English. In this regard, he resorts to folkloric transposition in which African folk stories, myths, mythical elements, fables, parables, proverbs, and idioms are interposed on the universality of communication of colonial language to make Nigeria palpable for the colonial other, and for those who are "alien" with that culture. Through such technique he imposes the particularity of African linguistic identity on a European text: "Achebe has produced a fictionalized, sociolinguistic study which demonstrates his linguistic principles and evokes that very horror as the direct result of the cultural disintegration which necessarily follows the abandonment of linguistic identity" (Wasserman in lyasere 84).

Folkloric transposition is the imposition of "conservative or traditionalist" (Ong 40) which Ong counts as a characteristic to set off orality from literacy. In textual cultures, knowledge is preserved in writing system, while primary oral cultures preserve and transmit knowledge through the sayings of the elders, proverbs, myths and so forth:

Knowledge is hard to come by and precious, and society regards highly those wise old men and women who specialize in conserving it, who know and can tell the stories of the days of old. By storing knowledge outside the mind, writing and, even more, print downgrade the figures of the wise old man and the wise old woman, repeaters of the past, in favor of younger discoverers of something new. (Ong 41) 
Entangling elements of Ibo literary culture within colonial literary genre subverts the hierarchical walls between the two. This is parallel with the situation Bakhtin describes when folk humor entered Renaissance literature "the walls between official and unofficial literature were inevitably to crumble, especially because in the most important ideological sectors these walls also served to separate languages" (Bakhtin, Rabelais and His World 72).

Ibo folktales, in general, explain Ibo worldviews while mythological tales are the basis of oral history as they tell about the origins of Ibo communities, Ibo wars and tribal heroes. And like other societies, myths in African culture explain the wonders of nature, provide the narratives of the creation, and recount the activities of divine beings. Legends, on the other hand, generally describe the actions of people and often commemorate heroes. Unlike innovative current proverbs which form the dynamic aspect of Ibo language, folk tales and myths, transmitted from one generation to the next as embodiment of collective folk mind, constitute the noncreative static aspect of lbo language while they serve the purpose of oral literature which is not only entertainment but also instruction.

The imposition of myths, legends and folktales upon an African narrative written in European language is for the greater purpose of bringing the local to the universal scale as myths have both national and universal overtones. Myths are by nature collective and communal; they bind a tribe or a nation together in common psychological and spiritual activities. In The Language of Poetry, edited by Allen Tate, Philip Weelwright explains, "Myth is the expression of a profound sense of togetherness of feeling and of action and of wholeness of living" (11). Moreover, myth is a dynamic factor everywhere in every human society; it has the capacity to transcend time, to unite the past (traditional modes of belief) with the present (current values) and reach the future (spiritual and cultural aspirations). Because of the ubiquity of myth in time and place, the existence of mythological accounts in 'national allegories' give nations the sense of dignified historical background. Besides the fact that such folkloric, mythic and legendary aspect of the narrative makes the works (of Achebe) relevant to a multitude of societies, rather than just those of Nigeria.

Spatial and temporal narrative treatments bind the whole stories of Things Fall Apart and Arrow of God with the myth of origin. First, the opening sentence of Things Fall Apart immediately locates Umoufia within uncertain physical borders: "Okonkwo was well known throughout the nine villages, and even beyond" (3). The vagueness with which the narrator indicates the outer limits of Okonkwo's fame reflects the tribe's limited awareness of its location in space, of its specific place in the world. According to Irele, the vagueness of spatial treatment also: "accords with the curious indefiniteness of its name, Umuofia, or "people of the forest," a name that also doubles as that of the novel's locale, designating a community firmly situated within the natural world" (Irele 8).

Second, not only the geographical borders of Umoufia are treated with the same uncertainty that we find in myths but also the temporal span of the story are vague:

The land of the living was not far removed from the domain of the ancestors. There was coming and going between them, especially when an old man died, because an old man was very close to the ancestors. A man's life from birth to death was a series of transition rites which brought him nearer and nearer to his ancestors. (Achebe, Things Fall Apart 86)

Achebe tries to impose the mythological time treatment of Ibo calendar on his narrative. In the traditional Ibo calendar, there are four days in a week the names of which are derived from the mythology of the Kingdom of Nri; Eke, Oye, Afo, and Nkwo. In such calendar, there are seven weeks in one month and a month has 28 days. Overall, there are 13 months in a year. (See Key to the Igbo language by Vin. Onyema Okeke) The traditional time keepers in Iboland are the priests; the point is clearly referred to in Arrow of God as priest Ezeulu is the one responsible for declaring the harvest time or the beginning of the new moon: "This was the third nightfall since he began to look for signs of the new moon" (1).

Unlike rural novels, with mythological time treatment, in urban novels there are explicit time references as the narrative is approaching the textual qualities of colonial prose. In A Man of the People there occurs a great distance from mythical time by referring to historical facts such as "the postal strike of 1963" (25) during which exchange of letters was impossible. Or referring to Chief Nanga's taking offence at his being called "M.A. Minus Opportunity", Samalu writes: "When I first knew Mr. Nanga in 1948 he had seemed quite happy with his nickname . . . in 1964 he was valiantly proving that a man like him was better without it" (26). Apart from clear temporal references, there are explicit spatial references: "I thought I should first pay a short visit to my home village, Urua, about fifteen miles from Anata" (27). Or regarding his girl friend, Elsie, Samalu lets us know that "Now she was working in a hospital about twelve miles outside Bori" (26). There are clear references to "the small trading town of Giligili" (41) where Samalu lived as a boy and "the completion of the road between Giligili and Anata" (42).

Mythic temporal references are evident in the language of the people who belong to the social class of adherents of rural traditional culture or the stratum of illiterate villagers. For example, Edna's father uses a mythic time to refer to the duration of her wife's illness: "Her body has not been hers since the beginning of the rainy season" (A Man of the People 
91). However, the social class of Western educated urban people, represented by Samalu or Nanga, has strict temporal and spatial references: "I returned to Ananta on $23^{\text {rd }}$ December" (85).

The third reason that makes the whole narrative of Achebe 's Things Fall Apart seem as the legend of Umoufia is the evocation of a wrestling contest between the eponymous founder of the town and "a spirit of the wild" which parallels the Old Testament story of Jacob wrestling with the angel, an encounter that leaves him forever lame: "the founder of their town engaged a spirit of the wild for seven days and seven nights" (1). The parallel suggests the mighty origin of African tribes.

Such mythic treatment of tribal origin establishes what Gikandi has called "the Igbo epistemology" (Gikandi 31-38). According to Irele "Thus, as represented by Chinua Achebe, and contrary to the discourse of colonial anthropology, Umuofia, the primordial Igbo village, emerges as a locus of reflective civility" (9). According to Jan Mohamed, "in its novelistic form the story of Okonkwo is unique and historical, yet it is told as if it is a well-known myth" (Whittaker et al 87).

Fourth, diverse topics of narratives sustained in the overall narrative of the novel are narrated as if they are circulated oral tales. For example, regarding the ritual sacrifice of Ikemefuna, the narrator says his story "is still told in Umoufia unto this day" (Achebe, Things Fall Apart 9), or regarding Okonkwo it is said that the story of his poverty "was told in Umoufia" (12). Diverse narrative pieces woven together are treated as communal property passed on from one generation to the next via oral narration. The story of Umuofia is also one that "the old men" (3) agreed was one of the most laudable exploits "since the founder of their town engaged a spirit of the wild for seven days and seven nights" (3).

Not only the whole account of Things Fall Apart is narrated as a sustained myth, people also lead a life based on mythic explanations. Ekwefi, Okonkwo's second wife suffers from child miscarriage her previous "nine children had [all] died in infancy, usually before the age of three" (Achebe, Things Fall Apart 55). Ekwefi links her problem to supernatural world by believing that "her own evil chi" denies her child. As the result of the matter, Ezinma tries to be linked with spiritual world by finding her iyi-uw.

In Things Fall Apart, collective folk mind concerning false sense of temporality is explicated via a folktale. Okonkwo during the Week of Peace loses his temper and beats his wife severely at which point he is described as "the little bird nza" in allusion to the tale of nza. Nza is a bird which overfeeds itself so much so that it forgets how little it once was and challenges hunters to shoot at it. Like the nza bird, Okonkwo's affluence blinds him so that he momentarily loses his sense of time.

Achebe also weaves folk tales into the texture of his narrative to illuminate lbo community values in both form and content of his narrative. As a case in point, the tale about the Earth and the Sky in Things Fall Apart emphasizes the interdependency of the masculine and the feminine. Apart from transmitting folk wisdom and cultural values, tales as well serve the functional end of commenting on current situation. As an instance, the narrated tale in chapter 11 of Things Fall Apart concerns a tortoise that could not fly yet claimed to speak for all the birds. The wisdom of the tale concerns the monologism of state system whereby a single individual or a single stratum claims to speak for all social strata. In Anthills of the Savannah His Excellency strives to be the single voice and in No Longer at Ease the Western-educated stratum of elites struggles to win the power dominancy. Achebe in his 1974 essay "Chi in Igbo Cosmology", comments on the language of his people, noting that:

Since lgbo people did not construct a rigid and closely argued system of thought to explain the universe and the place of man in it, preferring the metaphor of myth and poetry, anyone seeking an insight into their world must seek it along their own way. Some of these ways are folk tales [and] proverbs. (161, emphasis added)

Approaching the stylistic analysis of urban novels it appears that the narrative strategies though lean towards textuality to reflect the advance and ultimate settlement of colonial textual culture are still oral. In A Man of the People, Max in his inaugural political campaign speech does not hesitate to resort to the folk tale to concretize the political situation of the country for the villagers. He embarks on narrating the story of a hunter who shoots a big game at night, but due to the darkness cannot find it, so he turns back the next morning only to find out that two vultures are fighting over the game. In his anger, the hunter shoots the vultures. Max interprets the folktale for the audience:

You may say that he was foolish to waste his bullet on them but I say no. He was angry and he wanted to wipe out the dirty thieves fighting over another man's inheritance. That hunter is yourselves. Yes, you and you and you. And the two vultures-P.O.P. and P.A.P. . . (Achebe, A Man of the People 126) 
Chapter eight of Anthills of the Savannah narrates the myth of Idemili to impart the dangers of seeking power. In the middle of the myth, the narrator also seizes the opportunity to refer to the ancient origin of Nigeria, as ancient as the circulated myths:

Idemili, travelling through the country disguised as a hunter, saw this and on her return sent a stream from her lake to snake through the parched settlements all the way to Orimili, the great river which in generations to come strange foreigners would search out and rename the Niger. (94)

The myth is to stress the fact that before the arrival of "strange foreigners", the land had a history and civilization though the act of renaming the river by "strange foreigners" de-possessed the Africans from their inherited land. Through his relexified language, Achebe is able to give voice to a native Nigerian experience- and on broader scales African experience- throughout the English speaking world.

Achebe's cultural chronology is an answer to the Westerns who believed that culture and civilization spread from Europe to Africa as the Africans were the inferior race. The extreme form of this view is expressed in Grimm brothers' classic work Household Tales. In the introduction of this classical work it is stated that if any similarities were found between tales told in Africa and those told in Europe, the former should be seen as offshoots of the Indo- European culture: "The Grimm brothers made such a statement because they were working under the prejudice that culture can only spread from a superior to an inferior people, not the other way round-and Africa was of course considered racially inferior to Europe" (Okpewho 7). Moreover, it is stated that if similarities are found between African and European folktales that is because Europeans brought their tales to Africa during the period of slave trade (Thompson 438). In his rural works, Achebe interweaves the local tales which date back to African pre-colonized era. Regarding the point, textual moments of cultural overtones via linguistic or folkloric transpositions are moments of dialogical experience: "Bakhtin will accept that dialogism is only perceptible in very specific textual moments, when linguistic structures-syntactic, lexical or generic- appear as the expression of particular, delimited 'points of view"' (Hirschkop \& Shepherd 9).

While folks, legends and myths enforce rich Ibo cultural history on the language, proverbs impose folk wisdom and make it transfer from generation to generation. In Things Fall Apart, proverbs are often used by elders of the clan: "As the elders said, if a child washed his hands he could eat with kings. Okonkwo had clearly washed his hands and so he ate with kings and elders" (6). The contextual interpretation is that although Okonkwo was a young man, he became rich through hard work and personal achievements, and so he became one of the lords of the clan by taking some of the titles that the elder and greater men had taken (Obaa 8).

In Arrow of God, we read "We have a saying that a man may refuse to do what is asked of him but may not refuse to be asked, but it seems the white man does not have that kind of saying where he comes from" (86). The example clearly proves that for Ibo people proverbs are more than just sayings but have turned to unwritten folk rules by which people live.

Although in urban novels the style of writing approaches the prose form of Western textuality, the proverbs still run throughout the novel as the reminding residue of poetic language and oral culture of Ibo society. Samalu says "Our people have a saying that when one slave sees another cast into shallow grave he should know that when the time comes he will go the same way" (Achebe, A Man of the People 36). Samalu says this proverb when being guests at Chief Koko's house, he and Chief Nanga assumed that Koko was poisoned to death. Witnessing Nanga's tremendous fear, Samalu, through this proverb imparts the significance that Nanga felt personally threatened, otherwise he did not seem to concern for Koko.

In Anthills of the Savannah, the Abazonian elder who takes the honor of introducing Ikem to the crowd, through using a proverb, delicately reminds that Ikem Osodi, the successful editor of national Gazette, is from Abazon: "the cock that crows in the morning belongs to one household but his voice is the property of the neighborhood" (112). In fact the old man is implying that though lkem is now living in the capital city of Bassa to benefit the State politicians he is from Abazon. Oral cultures made frequent use of sayings and later on the practitioners of literacy followed this tradition: "Literate persons, from medieval florilegia collectors to Erasmus (1466-1536) or Vicesimus Knox (1752-1821) and beyond, have continued to put into texts sayings from oral tradition" (Ong 17).

Moving beyond micro-linguistic features or the strategies associated with translingualism, there are discourse conventions associated with myths, legends, folktales, aphorisms, incantations, tongue twisters and riddles found in the source language. Some Yorùbá and Igbo writers have used the conventions of storytelling in their native languages in the stories which they write in English. This has resulted in the production of "two distinctive tribal prose styles" in Nigerian literature (Lindfors 59). The Samoan writer Albert Wendt uses the conventions of Samoan storytelling in his English prose 
fictions. He is described as "the true heir of the Samoan storyteller, the tusitala, in that he can reproduce in dialogue many characteristic modes of speech..." (Bardolph 51).

In some case, instead of myths, legends or folks writers impose vernacular philosophies. As a case in point, R. K. Narayan and Raja Rao use Gandhian philosophy in their literary works. Regarding Narayan's novels and short stories, Goswami writes: "Gandhian philosophy is used as a backdrop to the events of day-to-day life" (74). In Waiting for the Mahatma, Narayan narrates the story of Sriram, the spoiled grandson of a rich grandmother, who is drawn to Mahatma Gandhi's philosophy through his interest in one of the followers of Gandhi, Bharati. In Kanthapura, Rao mingles Gandhian philosophy with the narration of an old rustic woman who tells the story of change brought about by colonial imposition.

The imposition of folks, myths, legends, fables, proverbs and vernacular philosophies reminds the colonized that they had a rich cultural history before colonial domination. However, above all these cultural elements have the subversive role of othering the Western reader. Believing that "not all experience can be contained by the English language or the corresponding prevailing European worldview" (Lewis 96), colonized writers imbue their texts with vernacular cultural elements to remind that in the colonized's eyes the Western reader unfamiliar with ethnic local culture and traditions is the other of the narratives.

\section{References}

Achebe, Chinua. A Man of the People. London: Heinemann, 1966. . Anthills of the Savannah. New York: Anchor Press, 1988. . "Colonial Criticism." Hopes and Impediments. New York: Doubleday Press, 1988.

."English and the African Writer", Transition 18:27-30, 1965.

. Morning yet on Creation Day. New York: Doubleday, 1975.

. No Longer at Ease. London: Heinemann, 1960.

"The Role of the Writer in a New Nation." African Writers on African Writing.

Ed. G.D. Killam. Evanston: NorthWestern University Press. 1973. 7-13.

. Things Fall Apart. Harlow: Heinemann, 1958.

Aegerter, L.P. (1997) "Michelle Cliff and the Paradox of Privilege", College English 59:898-915. 1997.

Asgarally, Issa. Ed. Étude pluri-disciplinaire sur l'exclusion à Maurice. Réduit: Government Printer, 1997.

Anand, M.R. Untouchable, London: Penguin Books. (1940)

Ashcroft, Bill, Gareth Griffith, and Helen Tiffin. Postcolonial Studies The Key Concepts (2 ${ }^{\text {nd }}$ ed). London and New York: Routledge, 2007. The Empire Writes Back: Theory and Practice in Post-colonial Literatures. London: Routledge, 1989. . (eds) The Post-Colonial Studies Reader, London: Routledge. 1995.

Baeumer \& Scaglione. The Emergence of National Languages

Bakhtin, Mikhail. The Dialogic Imagination: Four Essays. Ed. Michael Holquist. Trans. Caryl Emerson and Michael Holquist. Austin: University of Texas Press, 1981.

Rabelais and His World. Trans. Hélène Iswolsky. $2^{\text {nd }}$ ed. Bloomington: Indiana University Press, 1984.

. "Discourse in the Novel." Literary Theory: An Anthology. Eds: Rivkin and Ryan. Malden, Massachusetts: Blackwell Publishers Ltd, 1998. 32-45.

Bardolph, J. "Albert Wendt: A New Writer from Samoa", in B.Olinder (ed.) A Sense of Place: Essays in Post-Colonial Literatures, Gothenburg: Gothenburg University, Commonwealth Studies. 1984.

Bhabha, Homi K (Ed.), Nation and Narration, London: Routledge, 1990.

Boehmer, Elleke. Colonial and Postcolonial Literature, London: Oxford University Press, 1995.

"Postcolonialism." Literary Theory and Criticism. Ed. Patricia Waugh. Oxford and New York: Oxford University Press, 2006

Brathwaite, E. K. (1974) Contradictory Omens: Cultural Diversity and Integration in the Caribbean, Mona, Jamaica: Savacou Publications.

(1971) The Development of Creole Society in Jamaica, 1770-1820, Oxford: Oxford University Press.

Césaire, Aimé. "Interview with Aimé Césaire by Jacqueline Leiner," Tropiques 1 (1978), v-xxiv.

Chamberlin, J.E. (1993) Come Back to Me My Language: Poetry and the West Indies, Urbana and Chicago: University of Illinois Press.

Chaudenson, Robert. Le lexique du parler créole de La Réunion. Paris: Champion, 1974.

Clark, Katerina and Michael Holquist. Mikhail Bakhtin. USA: Harvard University Press, 1984.

Corballis, R. (1984) "Contemporary Maori Writing in English", in Olinder (ed.) (1984).

Coulmas, Florian \& Konrad Ehlich. Writing in Focus. Berlin: Mouton, 1983.

Crystal, David. The Cambridge Encyclopaedia of Language. $2^{\text {nd }}$ ed. 1997.

Cuttayen, Bam. Nuvo Lizur. Rose-Hill: MMMSP, 1977.

Cutter, M.J. (1997) 'An Impossible Necessity: Translation and the Recreation of Linguistic and Cultural Identities in Contemporary Chinese American Literature', Criticism 39:581-612.

Dathorne, O.R. "Amos Tutuola: The Nightmare of the Tribe", inB.King (ed.) Introduction to Nigerian

Degraff, Michel. "Linguists' Most Dang erous Myth: The Fallacy of Creole Excep-tionalism," Language in Society 34 (2005). 
Edgell, Zee. Beka Lamb. London: Heinemann, 1982.

Emenyonu, Ernest N. "Introduction." Emerging Perspectives on Chinua Achebe, Vol. 1, Ed. Emenyonu, Ernest. Trenton: Africa World Press Inc, 2004.

Emenyonu, N. Ernest and Iniobong I. Uko. Emerging Perspectives on Chinua Achebe. Vol. 2. Trenton: Africa World Press, 2004.

Fanon, Franz. Black Skin, White Masks, trans. C. L. Markmann (Pluto, 1986).

The Wretched of the Earth, trans. Constance Farrington, New Delhi: Penguin, 1967.

Fitzmaurice, S. "Aspects of Afrikaans in South African Literature in English", in Cribb (1999a): 166-89. 1999.

Gandhi, Leela, Postcolonial Theory: An Introduction. Edinburg: Edinburg University Press, 1998.

Gardner-Chloros, Penelope. Code-switching. Cambridge: Cambridge University Press, 2009. Gikandi, Simon. Reading Chinua Achebe: Language and Ideology in Fiction. London: James Currey, 1991.

Gordon, E. and Williams, M. "Raids on the Articulate: Code-Switching, Style-Shifting and PostColonial Writing", Journal of Commonwealth Literature 33(2): 75-96. 1998.

Goswami, Ketaki. Mulk Raj Anand Early Novels. New Delhi: PHI Learning Private Limited, 2009.

Grace, P. Waiariki, Auckland: Longman Paul. 1975.

Gumperz, J.J. and Cook-Gumperz, J. Language and Social Identity. Cambridge: Cambridge University Press. 1982.

Haugen, Einar. Language Conflict and Language Planning. Cambridge MA: Harvard UP, 1966.

Hazaël-Massieux, Marie-Christine.. "La littérature créole: Entre l'oral et l'écrit," in Les créoles français entre l'oral et l'écrit, ed. Ralph Ludwig (Tübingen: Gunter Narr, 1989): 277-305.

Hirschkop, Ken and David Shepherd. Bakhtin and Cultural Theory. Manchester and New York: Manchester University Press, 1989.

Hookoomsing, Vinesh. A Harmonized Writing System for the Mauritian Creole Language: Grafi-Larmoni. Réduit: University of Mauritius, 2004.

. "Langue créole, littérature nationale et mauricianisme populaire" in Anthologie De la Nouvelle Poésie Créole, ed. LambertFélix Prudent (Paris: L'Harmattan, 1984): 377-422.

Innes, C. L. The Cambridge Introduction to Postcolonial Literatures in English. New York: Cambridge University Press, 2007.

Irele, Abiola. "The Tragic Conflict in the Novels of Chinua Achebe." Critical Perspectives on Chinua Achebe. Eds. C. L. Innes and Bernth Lindfors. Washington D.C.: Three Continents Press, 1978.

Izevbaye, D.S. "Nigeria", in B.King (ed.) Literatures of the World in English, London: Routledge \& Kegan Paul. 1974.

Jaggi, Maya. "Storyteller of the Savannah." Guardian Weekly. Dec. 28, 2000- Jan. 3,2001. 10-11.

James, L. (2000) Caribbean Literature in English, London: Longman. 2000.

Jussawala, F. and Dasenbrock, R.W. Interviews with Writers of the Postcolonial World, Jackson: University Press of Mississippi. 1992.

Kachru, B.B. (1986) The Alchemy of English, Oxford: Pergamon. 1986.

. (1995) "The Speaking Tree: A Medium of Plural Canons", in M.L.Tickoo (ed.) Language and Culture in Multilingual Societies. Singapore: SEAMEO Regional. 1995. Karrer, W. and Lutz, H. (1990) "Minority Literatures in North America: From Cultural Nationalism to Liminality", in W.Karrer and H.Lutz (eds) Minority Literatures in North America: Contemporary Perspectives, Frankfurt: Peter Lang. 1990.

Lal, P. and Rao, K.R. Modern Indo-Anglian Poetry. Delhi: Kavita. 1959.

Lewis, Alexandra. "Postcolonial Literatures and the Ongoing Process of 'Writing back'." Journal of African Literature and Culture. 78 (2005): 36-116.

Lindfors, B. (1971) "Characteristic of Yoruba and Igbo Prose Styles in English", in A.Rutherford (ed.) Common Wealth, Aarhus: Akademisk Boghandel. 1971.

Loomba, A. (1998) Colonialism I Postcolonialism, London: Routledge.

Mangan, J. "Too Sexy for Singapore, It's The Curse of The Romantic". The Age (News) 26 August: 7. 1998.

Maya, D. Narrating Colonialism: Postcolonial Images of the British in Indian English Fiction. New Delhi: Prestige, 1997.

Mcleod, John. Beginning Postcolonialism, London: Manchester University Press, 2007.

Merriam Webster's Collegiate Dictionary. 11 th ed, Massachusetts: Incorporated Springfiled: 2004.

McGuirk, C. Robert Burns and the Sentimental Era, Athens, Georgia: University of Georgia Press. 1985.

Mooneeram, Roshni. From Creole to Standard: Shakespeare, Language and Literature in a Postcolonial Context. Amsterdam: New York, 2009.

Moutou, Benjamin. Les chrétiens de l'île Maurice. Port-Louis: Best Graphics, 1996.

New, W. H. "New Language, New World". The Postcolonial Studies Reader. London and New York: Routledge, 1995. (303-308)

Ojaide, Tanure. "Examining Canonization in Modern African Literature." Asiatics 3. 1 (June 2009): 2-20.

Okara, G. "African Speech, English Words", Transition 10:15-16. 1963.

.The Voice, London: Heinemann, [1964] (1970).

Okpewho, Isidore. African Oral Literature: Backgrounds and Continuity. Bloomington: Indiana University Press, 1992.

Omole, J.O. "Code Switching in Soyinka's The Interpreters", in E.L.Epstein and R.Kole (eds) The Language of African Literature, Trenton, NJ: Africa World Press. 1998.

Ong. Walter J. Orality and Literacy: The Technologizing of the Word. London: Routledge, 1993.

Rajan, G. and R. Mohanram, eds. Postcolonial Discourse and Changing Cultural Contexts: Theory and Criticism. Westport, CT: Greenwood Press, 1995.

Ramharai, La Littérature Mauricienne d'expression creole. Port Louis [Mauritius]: Editions Les Mascareignes, 1990. 
Rodríguez, E.J. (1996) 'Oral Tradition and the New Literary Canon in Recent Caribbean

Poetry Anthologies', in Breitinger (ed.) (1996).

Said, W. Edward, Orientalism (2nd ed.), London: Penguin, 1995.

Culture and Imperialism, London: Vintage, 1993.

Saro-Wiwa, K. Sozaboy: A Novel in Rotten English. Port Harcourt: Saros International Publishers. 1985. .Four Farcical Plays. London: Saros International Publishers, 1989.

Scott, Patrick. "Gabriel Okara's The Voice: the Non-Injo Reader and the Pragmatics of Translingualism", in Research in African Literatures. Vol. 21, No. 3 (Autumn, 1990), pp. 75-88.

Article Stable URL: http://www.jstor.org/stable/3819635

Sebba, Mark. Contact Languages: Pidgins and Creoles. New York: Palgrave Macmillan, 1997.

Selvon, Sam. The Lonely Londoners. London: Longman. [1956] (1972).

Stewart, William (1965). "Urban Negro speech: Sociolinguistic factors affecting English teaching", in R. Shuy; A. Davis; R. Hogan, Social dialects and language learning, National Council of Teachers of English, pp. 10-18.

Talib, Ismail S. The Language of Postcolonial Literatures An Introduction. London and New York: Routledge, 2002.

Thomas, Douglas E. African Traditional Religion in the Modern World. Jefferson, North Carolina: McFarland and Company, 2005.

Walder, Dennis. Post-Colonial Literatures in English: History, Language, Theory. Oxford: Basil Blackwell. 1998.

Walsh, William. Commonwealth Literature. Oxford: Oxford University Press. 1973.

Waugh, Patricia. Literary Theory and Criticism. New York: Oxford University Press, 2006.

Weelwright, Philip. Metaphor and Reality. Indiana: Indiana University Press, 1975.

Wilkinson, J. (ed.) Talking with African Writers: Interviews by Jane Wilkinson. London and Portsmouth: James Currey and Heinemann. 1992.

Williams, A.A. (1998) 'Mother Tongue: Inte rviews with Musaemura B.Zimunya and Solomon Mutswairo', The Journal of African TravelWriting 4:36-44. Online. Available HTTP: http://www.unc.edu/ ottotwo/mothertongue.html (May 2000).

Whittikar, David and Mpalive-Hangson Msiska. Chinua Achebe's Things Fall Apart. Abingdon: Routledge, 2007.

Young, P. "Mechanism to Medium: The Language of West African Literature in English", in A.Rutherford (ed.) Common Wealth. Aarhus: Akademisk Boghandel. 1971.

. (1973) 'Tradition, Language and the Reintegration of Identity in West African Literature in English', in E.Wright (ed.) The Critical Evaluation of African Literature, London: Heinemann.

Young, R. J. C. (1995) Colonial Desire: Hybridity in Theory, Culture and Race, London: Routledge.

Zabus, Chantal. "Relexification." The Postcolonial Studies Reader. $2^{\text {nd }}$ ed. Eds. Ashcroft et al. London and New York: Routledge, 2006. 285-289. 